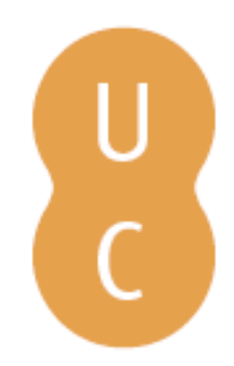

\title{
pommalina
}

\section{The development of a web-application for improved wildfire risk management in} Lebanon

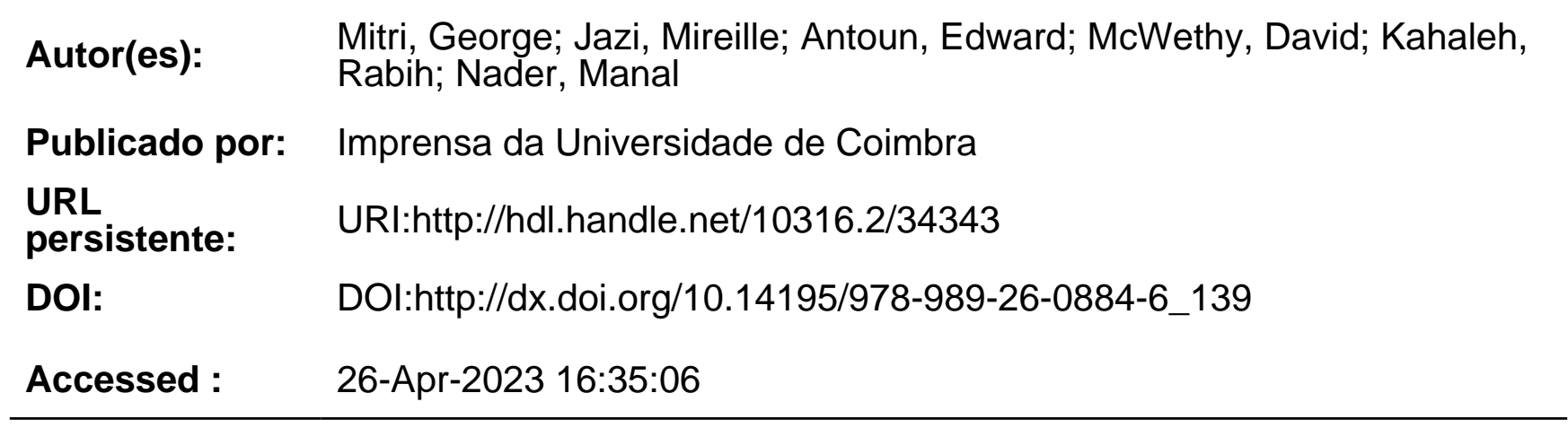

A navegação consulta e descarregamento dos títulos inseridos nas Bibliotecas Digitais UC Digitalis, UC Pombalina e UC Impactum, pressupõem a aceitação plena e sem reservas dos Termos e Condições de Uso destas Bibliotecas Digitais, disponíveis em https://digitalis.uc.pt/pt-pt/termos.

Conforme exposto nos referidos Termos e Condições de Uso, o descarregamento de títulos de acesso restrito requer uma licença válida de autorização devendo o utilizador aceder ao(s) documento(s) a partir de um endereço de IP da instituição detentora da supramencionada licença.

Ao utilizador é apenas permitido o descarregamento para uso pessoal, pelo que o emprego do(s) título(s) descarregado(s) para outro fim, designadamente comercial, carece de autorização do respetivo autor ou editor da obra.

Na medida em que todas as obras da UC Digitalis se encontram protegidas pelo Código do Direito de Autor e Direitos Conexos e demais legislação aplicável, toda a cópia, parcial ou total, deste documento, nos casos em que é legalmente admitida, deverá conter ou fazer-se acompanhar por este aviso.

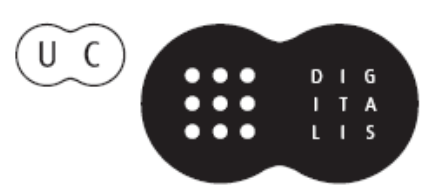




\section{ADVANCES IN}

Forest Fire

\section{RESEARCH}

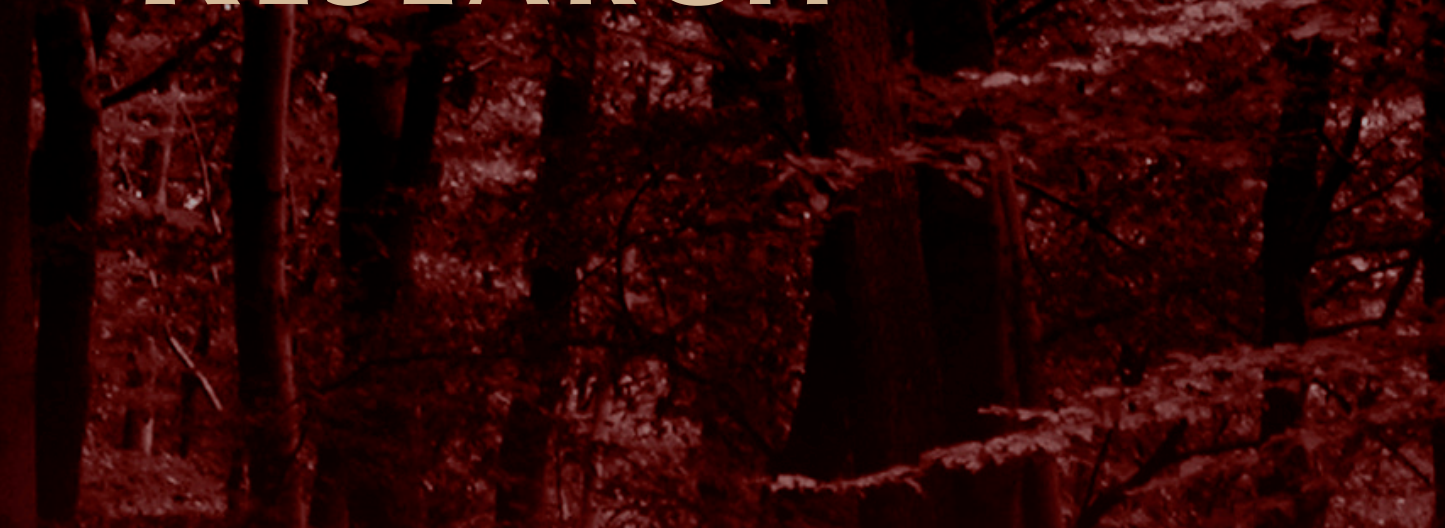

\section{DOMINGOS XAVIER VIEGAS}

\section{EDITOR}




\title{
The development of a web-application for improved wildfire risk management in Lebanon
}

\author{
George Mitri ${ }^{\mathrm{a}}$, Mireille Jazi ${ }^{\mathrm{a}}$, Edward Antoun ${ }^{\mathrm{a}}$, David McWethy ${ }^{\mathrm{b}}$, Rabih Kahaleh $^{\mathrm{c}}$, Manal Nader ${ }^{\mathrm{a}}$ \\ ${ }^{a}$ Institute of the Environment, University of Balamand, Lebanon, george.mitri@balamand.edu.lb \\ ${ }^{b}$ Department of Earth Sciences, Montana State University, Montana, USA \\ ${ }^{c}$ Department of Information Technology, University of Balamand, Lebanon
}

\begin{abstract}
Lebanon's National strategy for forest fire management emphasizes the need to enhance the capacity of stakeholders in Lebanon to assess and manage wildfire in light of future climate change and residential expansion into wildland areas. In this context, we developed a web-based decision framework to improve fire risk management. The primary objective of the application (FireLab) was to provide an online user-friendly interface for displaying data that are critical for making informed fire-management decisions. Data include 257 variables related to fire activity, risk, and hazard and are generated at the municipality level for all of Lebanon. FireLab is delivered through a web browser, making it widely accessible to the public in a format that allows users to easily display wildfire conditions and to describe and share modeled wildfire potential scenarios of current and future conditions.
\end{abstract}

Keywords: wildfire risk management, climate change, web-application, decision framework

\section{Introduction}

During the past decade, Lebanon has experienced a number of large wildfires that have had dramatic impacts on large areas of forests and the livelihoods of local communities. In addition, projections for continued climate warming are likely to further promote fire risk (Salloum and Mitri, 2014).

While the risks of fires are increasingly becoming a concern, a common database documenting spatial and temporal patterns of fire and their proximity to settlements is lacking. Currently, there is little information with which to anticipate and predict which areas of Lebanon are most vulnerable to future fire risk and hazard data.

Previously, we set out to assess drought conditions in Lebanon based on climatic variability to gain a better understanding of the temporal and spatial changes in wildfire potential (Mitri et al., 2014). Wildfire potential was assessed with the use of spatial climatic data, and the temporal and spatial variability of wildfire potential was investigated accordingly. In addition, an updated wildfire risk map of Lebanon was produced involving the use of extensive biophysical and socio-economic datasets. Maps and models have long been an integral part of the environmental decision making process (Walker and Chapra, 2014). However, the abilities of resource managers, policy makers, and stakeholders to understand how these maps and models work and what they represent are limited due to the required technical expertise (NRC, 1999).

In this context, it was essential to build a generic and simple data infrastructure for individual communities to access in relation to their needs. The development of this infrastructure was important because land owners, managers, and decision makers have a major role in fire risk reduction for communities with different needs.

According to Goodall et al. (2011), the availability of online databases and models as web services allows for their inclusion not only in professional workflows, but also in interactive tools for data querying and simulation aimed at decision-making. The science of visualizing data has a long history (Tufte, 2001; Spiegelhalter et al. 2011). Implementing environmental models in a web context is necessary to help bridging the gap between high-level environmental data analysis and access and 
usability for and by the general public. This approach promises greater transparency and inclusive participation of citizens in environmental data monitoring, research, and decision-making (Buytaert et al., 2012).

Lebanon's National strategy for forest fire management (Decision No. 52/2009) highlighted the need of information to describe the magnitude and urgency of the problem to decision makers and make them prioritize the necessary measures to prevent or minimize fire risk (MOE/AFDC, 2009). In this context, the development and dissemination of detailed information on fire risk assessment and monitoring across Lebanon is critical to improve fire risk management at both local and National levels.

To address these needs, we developed a web-based application to host multiple data types related to fire risk and management. The primary objective of the application (called FireLab) was to provide an online user-friendly interface where relevant fire data can be accessed to make informed firemanagement decisions.

\section{Methods}

The development of the web-application model comprised 1) the web browser or the user interface, 2) the dynamic content generation technology, and 3) the database server containing all generated data (Figure 1).

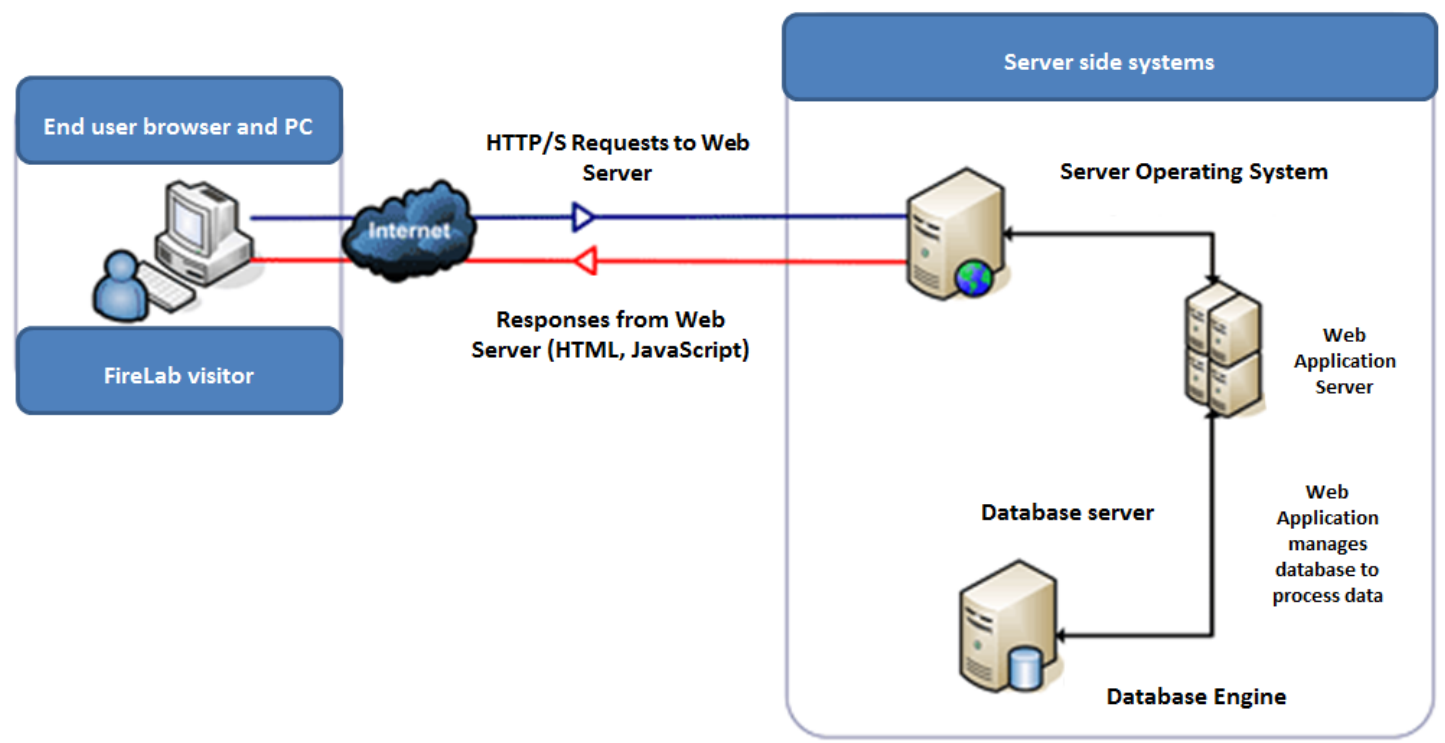

Figure 1. Architecture of the web-application model

The user interface was designed to be self-exploratory and easy to use. Users only need to provide minimal input to achieve the desired outputs. Technically, the web-application queries the content server (a content repository database) and dynamically generates web documents to serve to the user. The documents are generated in a standard format to allow support by all browsers (e.g., HTML). In addition, the development of the web-application involved the use of Microsoft Visual Studio 2010, C\#, asp.net and JQuery. The technology is accessible by all electronic tablets and mobile phones, easily accessed by mobile operators, reliable, secure, and without major technological restrictions.

The database comprised 257 variables generated at the village level and covering the entire country. The variables included information about landcover/landuse, fire hazard, vulnerability, overall fire risk (Figure 2), future fire hazard in association with projected climatic data, and Wildland-Urban Interface (WUI), among others. Most importantly, the application allows data to be constantly updated in the system so that new information can be used to guide management. Finally, a comprehensive glossary 
was developed and integrated in the system describing the main terminologies employed in the queries of the application.

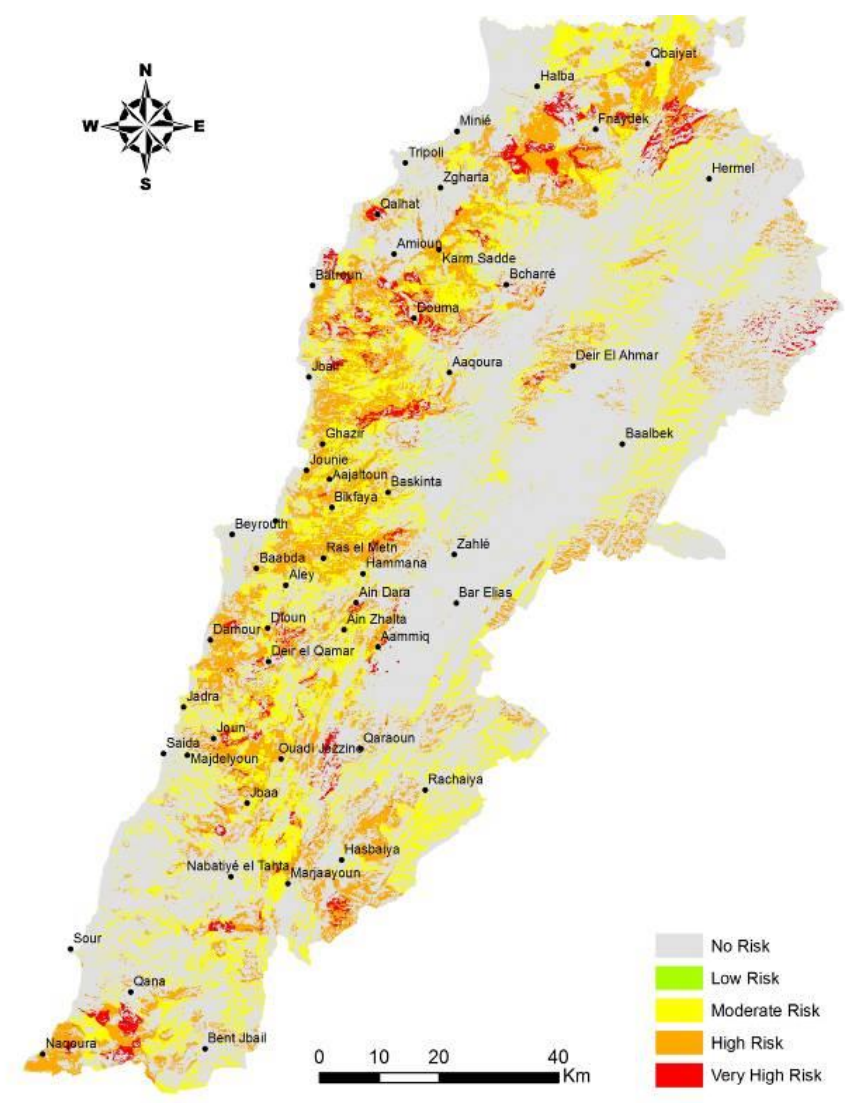

Figure 2. Overall fire risk map of Lebanon

\section{Results and discussion}

The main four queries of the web-application interface (Figure 3) included: 1) the selection of the area of interest (e.g., village) and the visualization of a specified type of information for the selected area in form of tables and diagrams, 2) the listing and sorting of summary statistics of required information in a country table view, 3 ) the listing and sorting of summary statistics of required information for a group of administrative units (e.g., villages) within the same broader administrative unit (called Kadaa), 4) the generation of a detailed wildfire profile including a full graphical report about each category of available data for each individual village, and 5) the generation of an annual country profile of fire statistics (based on field collected data previously entered in the database). In addition, the webapplication allows further data entry through private access.

The user interface included an administrative map for each Mohafazat (administrative region) in Lebanon. These comprised Bekaa, Beirut, Nabatieh, North and Akkar, Mount Lebanon and South. The user has the possibility to select the Mohafazat of interest, visualize its coverage map and the name of each village, and select the village of interest. Accordingly, all data for the selected village can be visualized in form of tables and graphs. A full report of each village can be generated in a PDF format. 
Overall, the application was not only viewed as a scientific tool, but also it was considered as a management and outreach mechanism. This is reflected in its capability of providing the public with the data needed at different levels, namely at the municipality, regional, and National levels. Also, the fact that the application allows further data entry in the system based on a specific data entry sheet, makes it a dynamic tool that incorporates new information with which to inform management.

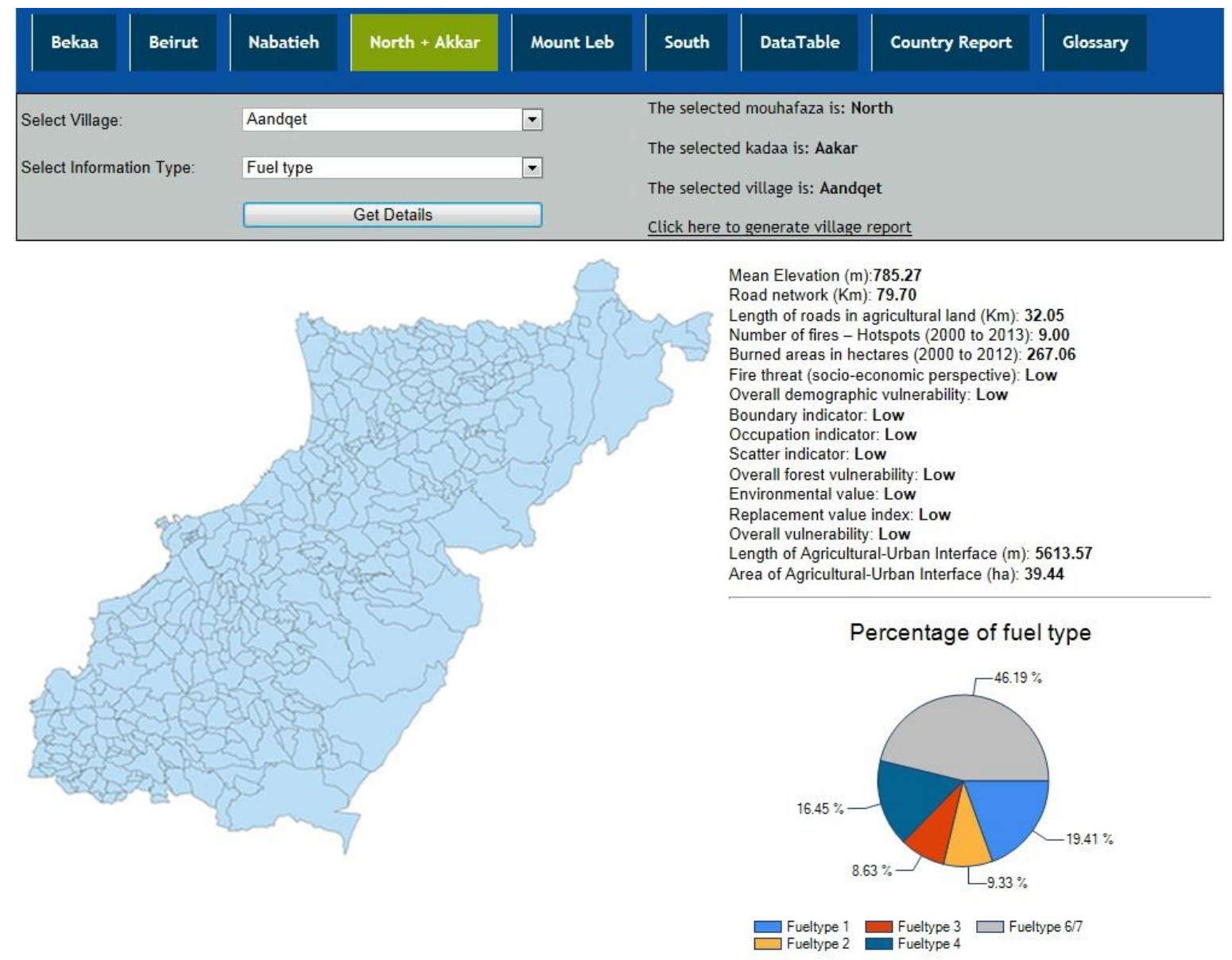

Figure 3. A screen shot of the main interface of the web-application

\section{Conclusions}

With projections for increased fire activity in Lebanon there is a critical need to provide spatially explicit wildfire data with which to assess fire risk and hazard at the village level. To address this need, we made fire data publicly available through an online web-application and within a framework where management decisions could easily be made. Additionally, we developed a structure where users can contribute to the development and dissemination of new knowledge, and to a more transparent and effective decision-making and policy assessment. Future work will involve collecting feedback from end-users on the use of such developed tool in order to evaluate its functionality and future improvement.

\section{Acknowledgements}

This material was published in association with the project "Towards a better assessment and management of Wildfire Risk in the Wildland-Urban Interface in Lebanon: gaining from the US 
experience" supported by the Partnerships for Enhanced Engagement in Research (PEER), sponsored by USAID. The contents do not necessarily reflect the views of USAID or the United States Government.

\section{References}

Buytaert W, Baez S, Bustamante M, Dewulf A (2012). Web-Based Environmental Simulation: Bridging the Gap between Scientific Modeling and Decision-Making. Environmental Science and Technology 46, 1971-1976.

Goodall JL, Robinson BF, Castronova AM (2011) Modeling water resource systems using a serviceoriented computing paradigm. Environmental Modelling and Software, 573-582.

Mitri G, Jazi M, McWethy D (2014) Investigating temporal and spatial variability of wildfire potential with the use of object-based image analysis of downscaled global climate models. South-Eastern European Journal of Earth Observation and Geomatics 3, 251-254.

MOE/AFDC (2009) Lebanon's National Strategy for Forest Fire Management. Decision No. 52 - 2009 (Mitri, G. Editor). A publication of the Ministry of Environment and the Association for Forests, Development and Conservation - Beirut, Lebanon.

NRC (1999) National Research Council (NRC). New strategies for America's watersheds. National Academies Press, Washington, D.C.

Salloum L, Mitri G (2014) Assessing the temporal pattern of fire activity and weather variability in Lebanon. International Journal of Wildland Fire. doi: 10.1071/WF12101.

Spiegelhalter D, Pearson M, Short I (2011) Visualizing uncertainty about the future. Science 333, 1393-1400. doi: 10.1126/science.1191181.

Tufte E (2001) The Visual Display of Quantitative Information; Graphics Press: Cheshire, CT,

Walker J, Chapra S (2014) A client-side web application for interactive environmental simulation modeling. Environmental Modelling and Software, 55, 49-50. 